\title{
Clinical report of rare manifestation of Herpes Zoster in the mandibular nerve
}

\author{
Manifestação Clínica de Herpes Zóster em Nervo Mandibular \\ Manifestación clínica del herpes zóster en el nervio mandibular
}

Received: 03/24/2021 | Reviewed: 04/03/2021 | Accept: 04/06/2021 | Published: 04/18/2021

\author{
Victor Teixeira Prest \\ ORCID: https://orcid.org/0000-0001-6259-8608 \\ Paulo Picanço School of Dentistry, Brazil \\ E-mail: victorteixeiraprest@gmail.com \\ Radamés Bezerra Melo \\ ORCID: https://orcid.org/0000-0001-5466-5698 \\ Paulo Picanço School of Dentistry, Brazil \\ E-mail: radamesbmelo@hotmail.com \\ Carlos Diego Lopes Sá \\ ORCID: https://orcid.org/0000-0002-7501-4170 \\ Paulo Picanço School of Dentistry, Brazil \\ E-mail: carlos.diego@facpp.edu.br \\ Nayara Cristina Monteiro Carneiro \\ ORCID: https://orcid.org/0000-0001-7722-8626 \\ Instituto Odontológico das Américas(IOA), Brasil \\ E-mail: nayaracarneirobmf@gmail.com \\ Ranelle de Souza Bernardino \\ ORCID: https://orcid.org/0000-0001-8810-4231 \\ Paulo Picanço School of Dentistry, Brazil \\ E-mail: ranellebernardes@gmail.com \\ Victor Pinheiro Feitosa \\ ORCID: https://orcid.org/0000-0001-8795-9967 \\ Paulo Picanço School of Dentistry, Brazil \\ E-mail: victor.feitosa@facpp.edu.br
}

\begin{abstract}
Herpes zoster (HZ) - a viral infection commonly known as shingles - is caused by reactivation of the varicella-zoster virus (VZV), one of eight known herpes viruses that infect humans. It is ubiquitous and highly contagious, with initial exposure usually occurring during childhood, when it causes chickenpox. The mechanism responsible for reactivating the virus is still not fully understood. However, it appears to be associated with a weakened immune system, with stress also having been identified as a possible triggering factor. Vesicular-bullous lesions on the skin that follow the pathway of a particular nerve are typically the clinical basis for diagnosing HZ with no need for further laboratory testing. The objective of this study is to report a clinical case of a patient, 17 years old, diagnosed with $\mathrm{HZ}$ in the trigeminal nerve with involvement of the mandibular branch. There were vesicular-bullous skin lesions in the mesenteric region, the mandibular region and the lower lip, in addition to erythematous lesions on the tongue, with pain in all the affected regions. All lesions were located on the left side of the face and did not exceed the midline. The treatment was performed with acyclovir and pain medication (Paracetamol and Codeine Phosphate, Tylex ${ }^{\circledR} 30 \mathrm{mg}$ ), with complete resolution occurring in 30 days. The patient is undergoing a 6 month outpatient follow-up and did not exhibit any functional sequelae.
\end{abstract}

Keywords: Herpes zoster; Trigeminal nerve; Treatment.

\section{Resumo}

Herpes zoster (HZ) - uma infecção viral conhecida comumente como cobreiro - é causada pela reativação do vírus varicela-zoster $(\mathrm{VZV})$, um dos oito vírus herpes conhecidos que infectam seres humanos. Este vírus é onipresente e altamente contagioso, com exposição inicial geralmente ocorrendo durante a infância, quando causa a varicela. $\mathrm{O}$ mecanismo responsável pela reativação do vírus ainda não foi completamente esclarecido. No entanto, parece estar associado a um sistema imunológico enfraquecido, com o estresse também sendo identificado como um possível fator desencadeante. Lesões vesículo-bolhosas na pele que seguem o caminho de um nervo específico são tipicamente a base clínica para o diagnóstico de HZ, sem a necessidade de testes laboratoriais adicionais. O objetivo deste trabalho é relatar um caso clínico de um paciente de 17 anos com diagnóstico de HZ no nervo trigêmeo com envolvimento do ramo mandibular, e discutir esta condição. Foram observadas lesões de pele vesículo-bolhosas na região massetérica, na região mandibular e no lábio inferior, além de lesões eritematosas na língua, com dor em todas as regiões afetadas. Todas as lesões estavam localizadas no lado esquerdo da face e não excediam a linha média. O tratamento realizado com Aciclovir e analgésico (paracetamol e fosfato de codeína, Tylex® 30mg) se mostrou eficaz, ocorrendo resolução 
completa do quadro clínico em 30 dias. O paciente esteve em acompanhamento ambulatorial durante 6 meses, não apresentando qualquer sequela funcional.

Palavras-chave: Herpes zóster; Nervo trigêmio; Tratamento.

\section{Resumen}

El herpes zoster (HZ), una infección viral comúnmente conocida como culebrilla, es causada por la reactivación del virus varicela-zoster (VVZ), uno de los ocho virus del herpes conocidos que infectan a los humanos. Este virus es ubicuo y altamente contagioso, y la exposición inicial ocurre generalmente durante la niñez, cuando causa varicela. El mecanismo responsable de la reactivación del virus aún no se ha aclarado por completo. Sin embargo, parece estar asociado con un sistema inmunológico debilitado, y el estrés también se identifica como un posible factor desencadenante. Las lesiones cutáneas vesiculoampollosas que siguen el camino de un nervio específico son típicamente la base clínica para el diagnóstico de HZ, sin la necesidad de pruebas de laboratorio adicionales. El objetivo de este estudio es reportar un caso clínico de un paciente de 17 años diagnosticado de HZ en el nervio trigémino con afectación de la rama mandibular, y discutir esta condición. Se observaron lesiones cutáneas vesiculoampollosas en la región masetera, en la región mandibular y en el labio inferior, además de lesiones eritematosas en la lengua, con dolor en todas las regiones afectadas. Todas las lesiones se localizaron en el lado izquierdo de la cara y no superaron la línea media. El tratamiento realizado con Aciclovir y analgésico (acetaminofén y fosfato de codeína, Tylex ® 30mg) demostró ser efectivo, con resolución completa del cuadro en 30 días. El paciente fue seguido de forma ambulatoria durante 6 meses, sin secuelas funcionales.

Palabras clave: Herpes zoster; Nervio trigémino; Tratamiento.

\section{Introduction}

Herpes zoster (HZ) is more commonly known as shingles, from the Latin cingulum, for "girdle." This is because a common presentation of HZ involves a unilateral rash that can wrap around the waist or torso like a girdle (Rai, et al., 2016). It is usually characterized by a painful vesicular rash resulting from reactivation of the highly contagious Varicella Zoster virus (VZV), one of eight known herpes viruses that infect humans. First-time exposure typically takes place during childhood, whereby it causes chickenpox. Afterwards, the virus remains latent in the sensory ganglia, and its subsequent reactivation results in HZ. The mechanism responsible for reactivating the virus and the mechanism responsible for maintaining latency in the sensory ganglias are still not fully understood ( Wolfson, et al., 2019; Keskinruzgar, et al., 2015; Nair, et al., 2014).

$\mathrm{HZ}$ is more prevalent in elderly people, specifically those between 50 and 80 years of age, when $\mathrm{HZ}$ occurs in 5 to 10 per 1,000 persons. An important factor that explains this increased prevalence is that elders usually have a weakened immunologic system, due to their advanced age. It should be noted that all those with a compromised immune response, such as those who have undergone organ transplantation or recent chemotherapy for cancer, or individuals with HIV/AIDS, are at greater risk for developing HZ. Nevertheless, it may also infect younger patients. Stress or local trauma may also trigger the reactivation of the VZV (Keskinruzgar, et al., 2015).

This reactivation happens more commonly in the thoracic dermatomes, these representing over half of observed cases of the disease, with cranial nerves being affected in around 13\% of cases reported in the literature (Keskinruzgar, et al., 2015) . When the trigeminal nerve is involved, the ophthalmic branch (V1) is most affected followed by the maxillary branch (V2) and finally the mandibular branch (V3) (Arruda, et al., 2016). When HZ affects trigeminal nerve, oral and facial lesions may occur.

The prodromal symptoms of HZ infections include fever, burning, tingling, itching, and prickling sensations. The disease can often cause a vesicular rash that occurs unilaterally in the affected area, often accompanied by paresthesia and pain. Many complications can occur in the aftermath of an $\mathrm{HZ}$ infection, especially when the treatment is delayed. One of the most common complications is postherpetic neuralgia (PHN), a complication characterized by chronic neuropathic pain with persistence of at least one month in the path of the affected nerve. However, vasculopathy, meningitis, myelopathy, cerebellitis and ocular complications, such including conjunctivitis, optic neuritis, and ulcerations, may also occur (Guimarães, et al., 2021; Keskinruzgar, et al., 2015; Nair, et al., 2014).

Among the most serious complications of $\mathrm{HZ}$ infection are maxillary and mandibular alveolar bone necrosis, potentially 
leading to tooth exfoliation, although such complications are considered rare. Tooth neuralgia, internal root resorption, periodontitis, calcified and devitalized pulps, and periapical lesions are other dental indications of HZ (Rai, et al., 2016). Antivirals and analgesics are often used when treating HZ. Nonetheless, the efficacy of antiviral drugs in resolving oral complications associated with $\mathrm{HZ}$ can be questioned. Practitioners must be prepared to provide optimal treatment with the best prognostics, since such disease is occasionally found among dental patients.

The aim of this article is to report a case of $\mathrm{HZ}$ of the mandibular branch of the trigeminal nerve in a seventeen year old male patient and its subsequent treatment and follow-up.

\section{Methodology}

This paper is a qualitative, descriptive, case report study, based on the scientific literature with research of scientific articles in the Scientific Electronic Library Online (SciELO) and US National Library of Medicine (Pubmed) databases. Epidemiological data, photographic records and disease history were collected through physical and electronic medical records. The patient was aware of each step of the treatment and signed an informed consent form, allowing the use of his images and information for this article. For the present study, the ethical principles of the Declaration of Helsinki were respected.

\section{Case Report}

A 17-year-old male patient was referred to an institutional Oral and Maxillofacial Surgery service at a private Dental School at Fortaleza, Brazil. He had complaints of severe pain, along with burning sensations, pruritus, and blisters on the left side of the face, as well as malaise, fever and general discomfort in the same facial region since 3 days prior. The pain was severe, continuous and radiating in nature. He reported having felt the same signs 2 days before the development of these cutaneous lesions. By the clinical examination, vesicular-bullous skin lesions were observed in the periorbital, masseteric, genital and submandibular regions (Figures 1 and 2). In the intra-oral examination, erythematous lesions could be seen in the lower left region of the tongue and the gums. Due to these lesions, the patient was unable to maintain oral hygiene. The lesions did not surpass the midline of the face (Figures 1 and 2). There was no evidence of any carious lesion. Periodontal probing exhibited normal probing depths that were less than $3 \mathrm{~mm}$. 
Figure 1. Skin lesions presenting unilaterally, involving the area covered by the mandibular nerve.

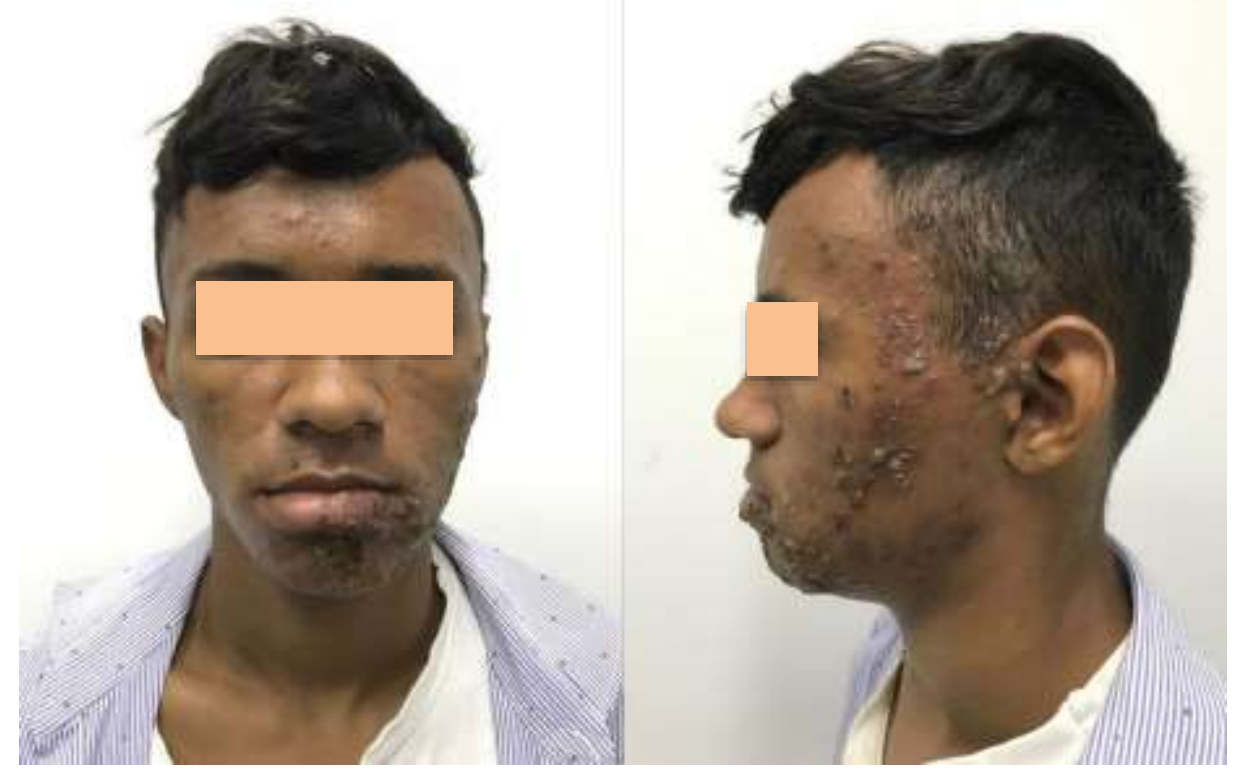

Source: Authors.

Figure 2. Lesions presenting unilaterally, involving the area covered by the mandibular nerve, including the lip, gum and tongue. The lesions on the tongue have a leukoitomatous aspect. The lesions never cross the midline.

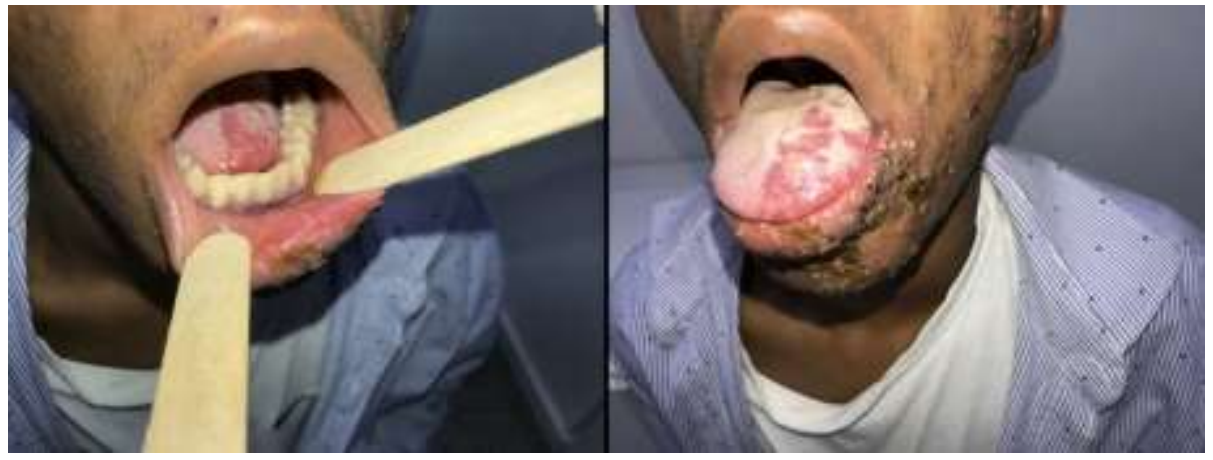

Source: Authors.

When asked about any previous medical history, the patient reported a clinical picture compatible with childhood varicella, in addition to the development of said disease by his younger brother having occurred in the previous month. Due to the typical appearance of the lesions following the path innervated by the mandibular branch of the trigeminal nerve, in addition to the prodromal and pathognomonic signs and symptoms, such as severe pain, itching sensations and fever, the clinical diagnosis of herpes zoster was established.

The treatment was administered with an antiviral drug (Acyclovir $800 \mathrm{mg}, 5$ times a day for 7 days), which showed an excellent response (Figures 3 and 4). For the severe pain, the patient was prescribed an analgesic drug (Paracetamol and Codeine Phosphate, Tylex ${ }^{\circledR} 30 \mathrm{mg}, 3$ times a day for 5 days). Complete resolution of all symptoms occurred in 30 days. After a six month follow-up, the patient did not exhibit any functional sequelae. 
Figure 3. Final intraoral aspect after the treatment.
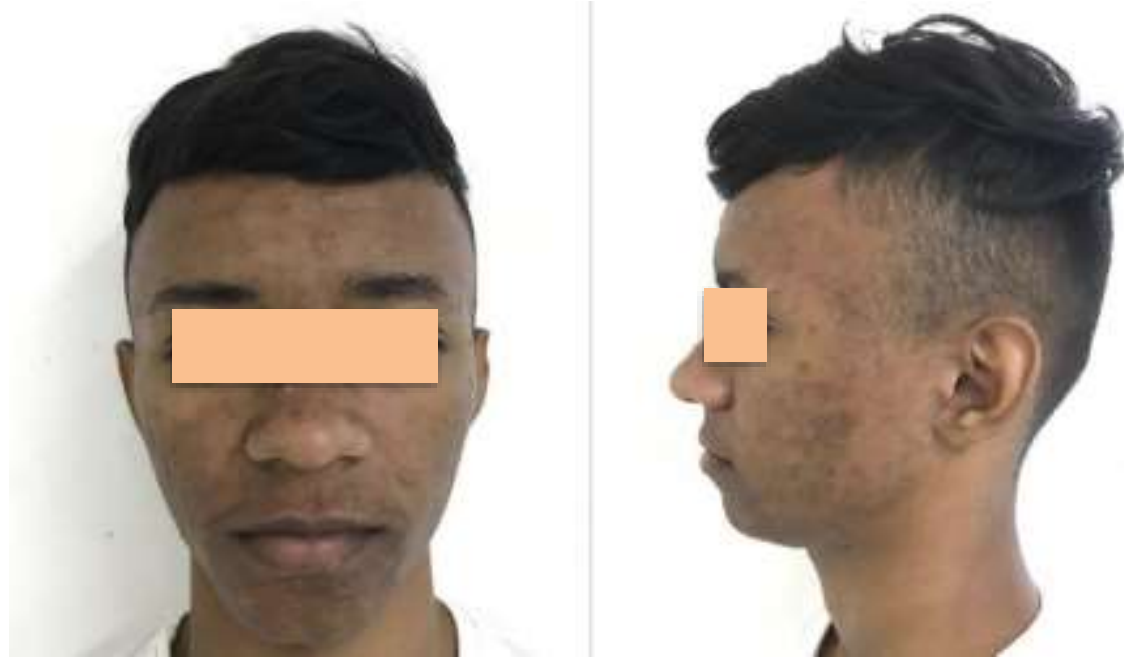

Source: Authors.

Figure 4. Final extraoral aspect after the treatment.
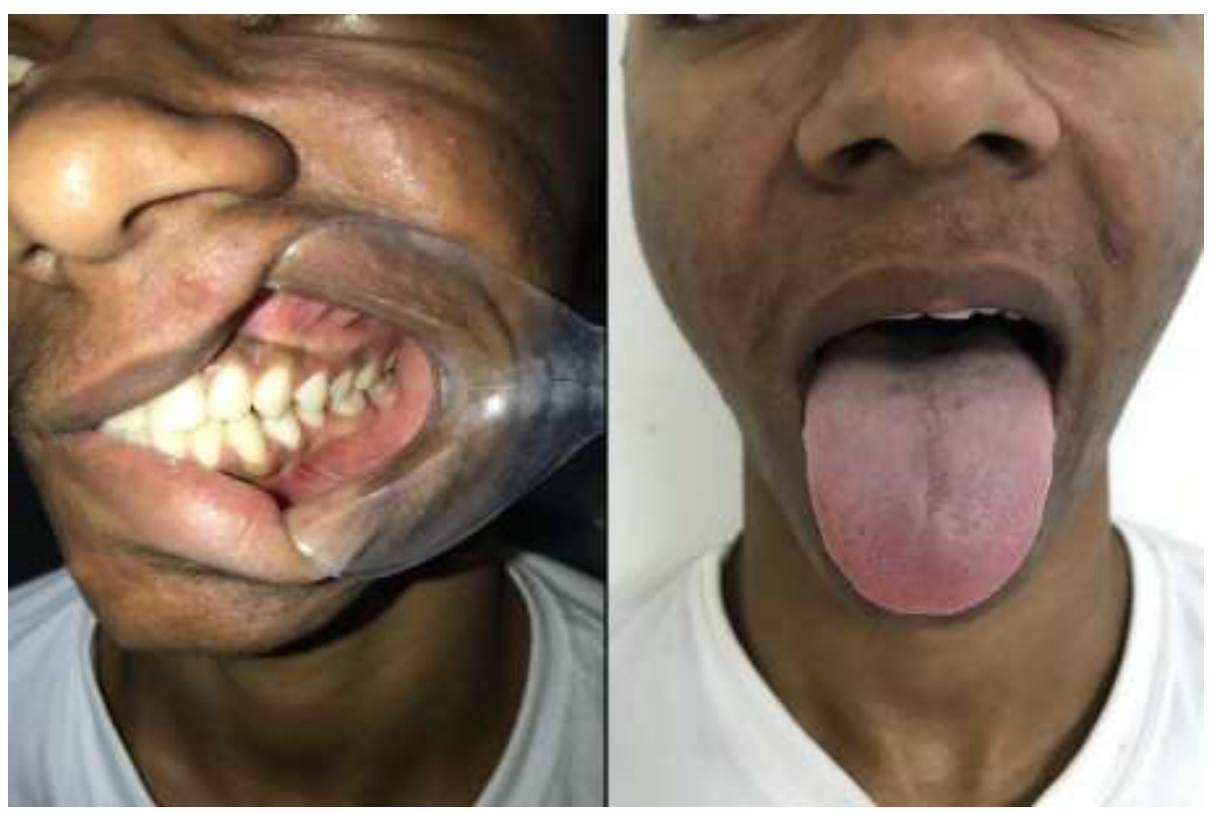

Source: Authors.

\section{Discussion}

The first exposure to the VZV can cause chickenpox, also known as varicella, an acute systemic disease in which the dominant feature is generalized vesicular rash. The virus may remain latent in the organism, and its subsequent reactivation causes HZ. This reactivation may be associated with many factors, usually related to a weakened immune system or the presence of certain viral infections. Some examples include the development of Ramsay Hunt syndrome, infections from other types of herpesvirus, such as Herpes simplex virus 1, Epstein-Barr virus, Cytomegalovirus, and the Roseola virus (Arruda, et al., 2016). Reactivation may also occur when in the presence of chickenpox, as evidenced by the present report.

One of the most important aspects that the practitioner must keep in mind by facing a herpes zoster infection is that the illness itself may indicate a presence of a non-diagnosed malignant neoplasm, such as Hodgkin's disease, leukemias or 
lymphomas (Silva, et al., 2013). Patients with HIV are also significantly (up to 15 times) more likely to develop HZ (Marra, et.al., 2020; Nair, et al., 2014). This is because the weakened immunologic system seems to be the major cause of varicella virus infection, and therefore the possibilities must be sought.

The epidemiology of $\mathrm{HZ}$ and the tendency toward reactivation of the latent virus can be influenced by host factors such as surgical stress, physical trauma, radiation therapy, and immunosuppressive therapy (Marra, et al., 2020; Keskinruzgar, et al., 2015). Another important triggering factor is the emotional condition of the patient. It has been documented that emotional stress seems to be an important factor for the onset of the infection (Dimisianos, et al., 2015).

$\mathrm{HZ}$ can also spread via direct contact with an infected person. The virus infects the cells of the respiratory tract or conjunctival epithelium and is carried through the body via the bloodstream and lymphatic system. It is then spread from the capillary epithelium to the epidermis where the viral replication destroys the basal cells (Rai, et al., 2016).

The prodromal stage of the disease, where there may be no signs of vesicles or ulcers, may lead to incorrect diagnosis of pulpitis which can lead to unnecessary endodontic treatment. Herpes Simplex Virus (HSV) infections appear in a similar fashion and, if localized and mild, may be mistaken for an $\mathrm{HZ}$ infection; both types can be differentiated by means of a viral culture. Other blistering or ulcerative diseases such as pemphigus or pemphigoid are chronic and do not present unilaterally, which is a differentiating diagnosis for the condition depicted herein (Rai, et al., 2016).

Typically, HZ begins with a prodrome of headache, photophobia, malaise, shooting pain, paresthesia, burning and tenderness along the course of the affected nerve (Arruda, et al., 2016). However, pain is the most frequently reported chief complaint.

Unilateral vesicles on an erythematous base appear in clusters, chiefly along the course of an affected nerve giving the characteristic clinical picture of single dermatome involvement. HZ presenting with pain and unilateral vesicles allows a straightforward diagnosis. In this regard, it is a diagnostic dilemma during the prodromal period when there is absence of lesions. Occasionally HZ may occur with pain along the course of the nerve but without the appearance of dermatome lesions, a condition known as Zoster Sine Herpete, which makes diagnosis more difficult (Rai, et al., 2016; Tidwell, et al., 1999).

Due to the fact that the infected epithelial cells are relatively superficial, varicella lesions commonly heal without scarring, although damage to the germinal layer of the epithelium may occur. Deep ulceration - characterized by necrosis of the entire dermal layer - is found with certain lesions (Keskinruzgar, et al., 2015). In the present patient, little to no scarring occurred, and patients recovering from $\mathrm{HZ}$ usually get over well and take over their lives naturally after healing (Silva, et al., 2013).

Whereas the disease may heal by itself in less than one month, there are cases in which chronic neuropathic pain along the pathway of the affected nerve may persist for longer periods - a complication known as postherpetic neuralgia (PHN) (Arruda, et al., 2016).

Also described in the literature are hypoalgesia of the maxillary branch of the trigeminal nerve and the development of peripheral facial paralysis, also called Bell's palsy (Arruda, et al., 2016). For these reasons, a follow-up period of at least 6 months is required. However, in the case reported, after the 6 months of follow-up, the patient did not develop any zoster-related sequelae.

The incidence of $\mathrm{HZ}$ in the general population has been reported to be $5.4 \%$. $\mathrm{HZ}$ infections typically occur in the individuals older than 45 years of age with the highest incidence among persons 60-90 years old (Keskinruzgar, et al., 2015).

Although $\mathrm{HZ}$ usually affects the thoracic nerve roots and the spine, the trigeminal nerve is involved in approximately $10-20 \%$ of cases. HZ primarily affects the ophthalmic branch, followed by the maxillary and mandibular branches. This suggests that $\mathrm{HZ}$ associated with the trigeminal branch of the mandibular nerve is fairly rare, especially without the involvement of other branches. Frequently, when the infestation affects the maxillary and mandibular branches, vesiculobullous lesions in the oral cavity may appear, unilaterally, as observed in the present patient (Arruda, et al., 2016; Nair, et al., 2014).

Treatment usually consists of antiviral drugs that accelerate the healing of rash, reduce the intensity and duration of 
acute pain, and probability the occurrence of PHN (Arruda, et al., 2016). Generally, analgesics such as aspirin, acetaminophen or ibuprofen, are also used in conjunction, even potentially helping in the case of PHN. The use of Medications such as corticosteroids, NSAIDS and tricyclic antidepressants has been reported in the literature (Rai, et al., 2016).

Several clinical investigations have proven the efficacy of antiviral agents in decreasing not only the duration of the rash but also the severity of pain related thereto. However, starting treatment within 72 hours of onset of the rash has been shown to be clinically more beneficial. Three of the most common antiviral agents used are Acyclovir, Valacyclovir and Famciclovir. Normally such drugs are well tolerated, although there may be some side effects, including nausea, abdominal pain, headache and vomiting (Rai, et al., 2016).

The use of opioids or regional nerve blockade may be required in patients experiencing severe pain. Local anesthesia may be injected around the affected nerves thereby providing pain relief that normally lasts between 12 and 24 hours, although the effectiveness of regional nerve blockade in reducing or preventing PHN is questionable (Rai, et al., 2016).

The generally accepted view is that the most effective method to reduce the morbidity of $\mathrm{HZ}$ and PHN is prophylactic vaccination with the zoster virus vaccine, which in itself reduces the risk of shingles by $70 \%$ to $90 \%$ (Keskinruzgar, et al., 2015; Hamborsky, et al., 2015).

\section{Conclusion}

While $\mathrm{HZ}$ infections affecting only the mandibular branch of the trigeminal nerve may be considered rare, it is important for the practitioner to understand their prodromal signs and symptoms to avoid taking any unnecessary course of action or delaying treatment. The VZV seems to be reactivated in the presence of varicella infections or when the patient has a weakened immune system. Treatment using antiviral drugs such as Acyclovir in the earlier stages of the disease has been shown to be effective not only in curing the disease, but also in avoiding any postherpetic symptomatology. With this knowledge, future studies can be carried out with this form of treatment, thus determining its full potential.

\section{References}

Arruda, J. A. A., Radnai, J. L. P. G., Silva, L. V. O., Souza Neta, I. F., Figueiredo, E. L., Alvares, P. R. \& Silveira, M. M. F. (2016) Zóster com Comprometimento do Nervo Trigêmeo: Relato de Caso. Rev. Cir. Traumatol. Buco-Maxilo-fac, Camaragibe 16 (4), 45-8.

Arvin, A.M. (1996) Varicella-zoster virus. Clin Microbiol Rev., 9 (3), 361-81. https://doi.org/10.1128/CMR.9.3.361-381.1996

Barratt, A. P., Katelaris, C. H., Morris, J. G. \& Schifter M. (1993) Zoster sine herpete of the trigeminal nerve. Oral Surgery, Oral Medicine, Oral Pathology, Oral Radiology, Endodontics, 75 (2), 173-5. https://doi.org/10.1016/0030-4220(93)90089-m.

Carbone, V., Leonardi, A., Pavese, M. \& Giordano M. (2004) Herpes zoster of the trigeminal nerve: a case report and review of the literature. Minerva Stomatol, 53 $(1-2), 49-59$.

Dimisianos, N., Ellul, J., Salakou, S., Tselengidou, E., Papachistou, P. \& Papathanasopoulos P. (2015). Trigeminal Herpes Zoster Complicated By Ramsay Hunt Syndrome, The Neurologist, 19 (2), 38-9. https://doi.org/10.1097/NRL.0000000000000004

Dolin, R., Reichman, R., Mazur, M. \& Whitley R. (1978) Herpes zoster-varicella infections in immunosuppressed patients. Ann Intern Med., 89, $375-88$. https://doi.org/10.7326/0003-4819-89-3-375

Gan, E. Y., Tian, E. A. \& Tey H. L. (2013) Management of herpes zoster and post-herpetic neuralgia. Am J Clin Dermatol., 14 (2): 77-85. https://doi.org/10.1007/s40257-013-0011-2

Gilden, D., Cohrs, R. J., Mahalingam R \& Nagel M. (2010) Neurological disease produced by varicella zoster virus reactivation without rash, Current Topics in Microbiology and Immunology, 342 (1): 243-53. https://doi.org/10.1007/82_2009_3

Guimarães, F., Pavelski, M. D., Dallazen, P., Santos, A. M de S., Delanora, L. A., Silva, W. P. P., Faverani, L. P. \& Magro Filho, O. (2021) Como identificar uma manifestação oral de Herpes-Zoster? Research, Society and Development. 10 (2), e31610212617. https://doi.org/10.33448/rsd-v10i2.12617

Hamborsky, J., Kroger, A. \& Wolfe, S. (2015) Epidemiology and Prevention of Vaccine-Preventable Diseases. Public Health Foundation, $13,353-74$.

Keskinruzgar, A., Demirkol, M., Ege, B., Aras, M. \& Au S. (2015) Rare involvement of herpes zoster in the mandibular branch of the trigeminal nerve: A case report and review of the literature. Quintessence Int., 46 (2), 163-70. https://doi.org/10.3290/j.qi.a32814 
Lambade, P., Lambade, D., Saha, T., Dolas, R., \& Pandilwar P. (2012) Maxillary osteonecrosis and spontaneous teeth exfoliation following herpes zoster, 16(4), 369-72. https://doi.org/10.1007/s10006-011-0303-8.

Lewis, M. \& Warren, K. (1980) Herpes Zoster Mandibularis. Canadian Journal of Neurological Sciences / Journal Canadien Des Sciences Neurologiques, $7(2): 153-5$.

Marra, F., Parhar, K., Huang, B. \& Vadlamudi, N. (2020) Risk Factors for Herpes Zoster Infection: A Meta-Analysis, Open Forum Infectious Diseases, 7(1). https://doi.org/10.1093/ofid/ofaa005

Mendieta, C., Miranda, J. \& Brunet, L. I. (2005) Alveolar bone necrosis and tooth exfoliation following herpes zoster infection: a review of the literature and case report. J Periodontol, 76(1), 148-53. https://doi.org/10.1902/jop.2005.76.1.148

Moffat, J., Stein, M., Kaneshima, H. \& Arvin M. (1995) Tropism of varicella-zoster virus for human CD4+ and CD8+ T lymphocytes and epidermal cells in SCIDhu mice. J Virol., 69(9), 5236-42. https://doi.org/10.1128/JVI.69.9.5236-5242.1995

Nair, P., Gharote, H., Singh, P. \& Jain-Choudhary P. (2014) Herpes Zoster on the face in the elderly. BMJ case rep. http://dx.doi.org/10.1136/bcr-2013-200101

Pereira, A., Shitsuka, D., Parreira, F. \& Shitsuka R. (2018) Metodologia da pesquisa científica. UFSM. https://repositorio.ufsm.br/bitstream/han dle/1/15824/Lic_Computacao_Metodologia-Pesquisa-Cientifica.pdf?sequence=1

Rai, N., Chattopadhyay, J., Abhinandan. \& Ghanta S. (2016) Herpes zoster infection of maxillary and mandibular branch. International Journal of Contemporary Medical Research, 3, 1437

Schmader, K., George, L., Burchett, B., Pieper, C. \& Hamilton J. (1995) Racial differences in the occurrence of herpes zoster. J Infect Dis., 171 (3), $701-4$. https://doi.org/10.1093/infdis/171.3.701

Silva, L., Castro, M., Ribeiro, C., Sobral, A., Souza, G. \& Silveira M. (2013) Herpes zoster facial - Relato de caso. Rev. Fac. Odontol. Porto Alegre, 53(2):379. https://doi.org/10.22456/2177-0018.37997

Siritho, S., Pumpradit, W., Suriyajakryuththana, W. \& Pongpirul, K. (2015) Severe Headache with Eye Involvement from Herpes Zoster Ophthalmicus, Trigeminal Tract, and Brainstem Nuclei. Case Rep Radiol. https://doi.org/10.1155/2015/402015

Siwamogsthan, P., Kuansuwan, C. \& Reichart P. A. (2006) Herpes zoster in HIV infection with osteonecrosis of the jaw and tooth exfoliation. Oral Dis., 12 (5), 500-5. https://doi.org/10.1111/j.1601-0825.2006.01230.x

Spátola A. (2010) Neuralgia pós-herpética - tratamento da dor neuropática com uso da toxina botulinica tipo A - apresentação de um caso. Med Reabil., 29(3), 74-

Tidwell, E., Hutson, B., Burkhart, N., Gutmann, J. \& Ellis C. (1999) Herpes zoster of the third branch of trigeminal nerve, a case report and review of literature. Int Endod. J., 32(1): 61-6. https://doi.org/10.1046/j.1365-2591.1999.00187.x

Wolfson, L. J, Daniels, V. J., Altland, A., Black, W., Huang, W., \& Ou, W. (2020) The Impact of Varicella Vaccination on the Incidence of Varicella and Herpes Zoster in the United States: Updated Evidence From Observational Databases, 1991-2016, Clinical Infectious Diseases, 70 (6), 995-1002. https://doi.org/10.1093/cid/ciz305 